\title{
NUTRITION AND METABOLISM
}

137

ZINC ABSORPIION IN AND DURING RECOVERY IRROM SI:VIERE MAI.NUTRITION IN CHILDHOOD. Barhara F. Golden \& Michat HIN Golden (spn by Prof J Golding) Tropical Metabolism Research Unit, University of the Weyl Indies, Aberdecil

Severely malnourished Jamaican children have evidence of hoth malabsorption and cim (Zn) deficiency, especially when they are oedematous. However, on high energy feeds, they are able to gain weight at greatly accelerated rates. By labelling their feeds with

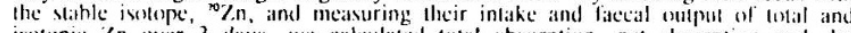
isotopic Zn over 3 days, we calculated tetal absorption, net absorption and, by difference, endogenous loss of $\mathrm{Zn}$ in groups of children, 8 lo 19 months old, with mar:asmus (n 4), with ocdemiltous malnutrition (n - 3), during ripid weighi gain following severe malnutrition (n - II) and alter their recovery to reterente weight-forength ('controls', $n=8$ )

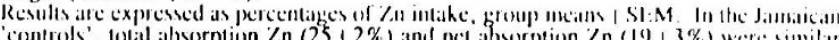
'controls', dolal absorption $\mathrm{Zn}(25,12 \%)$ and nct ibsorption $/ \mathrm{n}$ (19) $13 \%$ ) were similat to vilues in healthy U.S. children of similar age. However, comprared with the controls, lotal absorption $\angle n$ was lower in the children with ocedematous malnutition

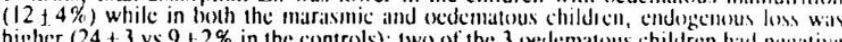
higher $(24+3$ vs $9+2 \%$ in the controls): Iwo of the 3 cedematous children had nejative

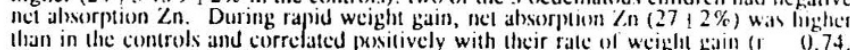
$p<0.01)$ : their endegenous hoss wis low $(5,2 \%)$

fhe results suggess that $\angle n$ malatosorption excurs particularly in ocdemaltous malnutrition but resolves rapidly during recovery.

\section{8}

EVALUATION OF THE BODY COMPOSITION AND THE BONE MINERAL CONTENT BY DUAL $X$ RAY ABSORPTIONIETRY. A. LAPILLONNE•, B.L.SALLE*, P.BRAILLONŞ, M.CIIAMBON*. Department of Neonatology* and Rhumatology\$ llopital Edouarú llerriot, LYON, FRANCE

An Ilologic QDR $1000 \mathrm{~W}$ system equiped with a special pediatric scanning program was used to evaluate total bone mineral content (BMCt), lean body mass and fat content. 65 infants were studied, gestational age ranged from 36 to 40 wecks : 28 were appropriate for gestational age (AGA), 24 were snall for gestational age (SGA) and 13 were infants of diabetic mothers (IDM). Mean birh weight (BW) \pm SD was $3116 \pm$ $557,2015 \pm 184$ and $3601 \pm 535$ grams: mean length $\pm S D$ wils $49.2 \pm 2.5,4.8 \pm$ $557,2015 \pm 184$ and $3601 \pm 535$ grams : mean length \pm SD wils $49.2 \pm 2.5,4.8 \pm$
1.9 and $49.8 \pm 2.9 \mathrm{~cm}$ respectively. The scan was performed during the first dity of life. BMCl (grams of hydroxyapatite), lean body mass (grams), fat content (grams), \% life. BMCt (grams of hydroxyapatite), lean body mass (grams), fat content (gran
BMCt, \% fat and \% lean mass were (results were expressed as mean \pm SD)

$B M C t, \%$ fat and \% lean mass were (results were expressed as mean \pm SD) :
\[ A G A(n=28) \quad \operatorname{SGA}(n=24) \quad \text { IDNI }(n=13) \]

\begin{tabular}{|c|c|c|c|}
\hline & $\operatorname{AGA}(n=28)$ & $\operatorname{SGA}(n=24)$ & IDM $(n=13)$ \\
\hline $\mathrm{BMCt}$, (grams) & $45.9 \pm 18.1$ & $24.9 \pm 9 \cdots$ & $68.3 \pm 21.7 \cdot$ \\
\hline Fat. (grams) & $457 \pm 148$ & $281 \pm 47 \cdots$ & $804 \pm 24 . \cdots$ \\
\hline Lean, (grams) & $2481 \pm 401$ & $1658 \pm 170 \cdots$ & $2545 \pm 4.44$ \\
\hline$\% \mathrm{BMCl}^{\circ}$ & $1.5 \pm 0.4$ & $1.2 \pm 0.5$ & $1.9 \pm 0.6 \cdots$ \\
\hline$\%$ Fat & $15.0 \pm 2.7$ & $14.3 \pm 2.1$ & $22.7 \pm 4.9 \cdots$ \\
\hline$\%$ Lean & $83.4 \pm 2.8$ & $80.8 \pm 17.6$ & $73.1 \pm 0 \quad \cdots$ \\
\hline
\end{tabular}

In this gestational age range ( 36.40 weeks), 1) $B M C t$ in $A G A$ group differed from In this gestational age range (36.40 weeks), 1) BMCt in $\mathrm{AGA}$ group differed from both SGA and IDM categories: BMCt wils better correlated with birthweight than with gestational age. 2) Body composition in \% of BW did not differ significamly between heavy birthweight.

\section{9}

THE SERUM TRANSFERRIN RECEPTOR AS INDICATOR OF IRON DEFICIENCY IN INFANTS

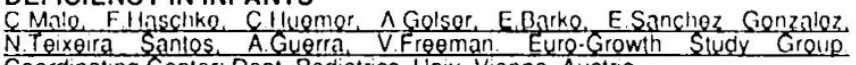
. Tanios A. Guerra , Freman. Euro-Grow

Objective: Serum transferrin receptor is now well established in adults as index of iron status. It increases with tissue iron need and is more sensitive than other parameters to mild iron deficiency. The purpose of this study was to test its value in infants, a population especially susceptible to iron deficiency.

value in infants, a population especially susceptible to iron deficiency.
Methods and setting: We measured hemogiobin, serum territin (RIAgnost, Methods and setting: We measured hemoglobin, serum territin (RIAgnost,
Behring) and the serum transferrin receptor (CLINIGEN EIA. Amgen Behring) and the serum transferrin receptor (CLINIGEN EIA, Amgen
Diagnostics) in 71 healthy infants at 12 months of age from 5 centers of the Diagnostics) in 71 healthy infants at 12 months of age from 5 centers
Euro-Growth Study (Vienna, Salzburg, Budapest, Bilbao, Porto. Dublin).

Results: Intra- and interassay variances of the transferrin receptor (TtR) Results: Intra- and interassay variances of the transferrin receptor (TIR)
measurements were $3.5 \%$ and $7.75 \%$, respectively. Infants with hemoglobin measurements were $3.5 \%$ and $7.75 \%$, respectively. Infants with hemoglobin
$(\mathrm{Hb})$ levels $<11 \mathrm{~g} / \mathrm{dl}$, indicating anemia, had significantly higher TtR values than infants with $\mathrm{Hb}$ values $>11 \mathrm{~g} / \mathrm{dl}(3.46 \pm 0.99$ vs $2.66 \pm 1.04 \mathrm{ug} / \mathrm{ml} ; p<0.05$. Wilcoxon rank test). In infants with $\mathrm{Hb}>11 \mathrm{~g} / \mathrm{d}$ l and $\mathrm{s}$-ferritin $<12$, between $12 \cdot 20$, and $>20$ $\mathrm{ng} / \mathrm{ml}$, TfR values were $3.04 \pm 1.13^{\circ}, 2.54 \pm 0.93$ and $2.18 \pm 0.64^{\circ} \mathrm{ug} / \mathrm{ml}$. respectively ("p<0.05, Duncans Multiple Range test). Regression analysis did not reveal a negative correlation between TfR and either $\mathrm{Hb}$ or s-ferritin.

Conclusions: Serum transferrin receptor is significantly increased in infants with iron deficiency anemia. In infants with no anemia $(\mathrm{Hb}>11 \mathrm{~g} / \mathrm{dl})$ but low iron stores (s-territin < 20) elevated transferrin receptor values already indicate iron deficient erythropoeisis. Although our data are limited the combination of serum ferritin and serum transterrin receptor appears promising as a screening tool for mild iron deficiency in infants.

\section{0}

FIRST TRIMESTER PHENYLKETONURIA (PKU) DIETARY COHTROL AND NEURODEVELOPMENTAL OUTCOME IN INFAHTS. Ann LoreK, JeHIY BaudL, Ja Towneend, Maggie Lilburn, Ann Stewart and David Brenton. Depts of Paediatrics and Medicine, University College London Medical School, London, UK.

To avold fotal damage in women with PKU, strict preconceptioti and pregnancy control of blood phenylalanine concentrations (PHE) have beet recommended (1). To find out if these recommendations prevented neurological damage we etudied the neurodevelopmental outcome of 24 infants from 23 pregnancies in which strict dietary control was introduced prior to conception. 18 had reached 1 year. Measures of outcome were related to mean PHE, and to number of days PHE exceeded $300 \mu \mathrm{mol} / 1$ in the first trimester. They included head circumference (OFC) and neurological examination at term and 1 year and developmental guotient fariffithe (SDS) at term and I year in infants of mothers with mean PHE $\$ 300$ (305(SDS) at term and 1 year in infants of mothers with mean PHE $>300$ (305496) $\mu \mathrm{mol} / 1$ were ignificantly amaller than those with mean PHE of $<300$ $(139-281) \mu \mathrm{mol} / 1$ (p<0.05). Within the group with mean PHE $<300 \mu \mathrm{mol} / 1$,
OFC SDS was lower in those whose PHE exceeded $300 \mu \mathrm{mol} / 1$ for more than OFC SDS was lower in those whose PHE exceeded 300 ymol/1 for more than 10 days $(p<0.05) .17$ of the 24 infants examined at term, and 13 of the 18 at 1 year, had abnormal neurological aigna. The mean GQ of these 18 infants was $109+13$ and did not differ according to PHE. We conciude that a) mean $\mathrm{PHE}$ of $<300 \mu \mathrm{mol} / 1$ in the firet trimester improves head growth especially when control is otrict b) atrict control at thi 1. MRC Working Party on PKU. Arch Dis Child 1993;68:426-427.

\section{1}

PROTEIN METABOLISM IN VENTILATED PRETERM INFANTS ON THF FIRST DAY OF LIFE.

J.B. Van Goudoever, J.L.D. Wattimena, P.J.J. Sauer. Department of Pediatrics, Sophia Childrens Hospital, Erasmus University Rotterdam, The Netherlands.

Protein kinetics were measured to examine the effect of immediate commencement of amino acid (AA) administration following birth. Eight infants (birth wl $1.5 \pm 0.3 \mathrm{~kg}$ ) received exclusively $6.6 \pm 1.4 \mathrm{~g}$ glucose $/ \mathrm{kg} / \mathrm{d}(26 \mathrm{kcal} / \mathrm{kg} / \mathrm{d})$ and seven infants (bw $1.4 \pm 0.4 \mathrm{~kg}$ ) received $5.9 \pm 2.0 \mathrm{~g}$ giucose $/ \mathrm{kg} / \mathrm{d}$ and $1.2 \pm 0.1$ $\mathrm{g} \mathrm{AA} / \mathrm{kg} / \mathrm{d}(28 \mathrm{kcal} / \mathrm{kg} / \mathrm{d})$. All infants were ventilated and studied at the first day of life. A primed continuous infusion of $\mathrm{NaH}^{13} \mathrm{CO}_{3}$ was followed by a primed continuous infusion of $\left[1-{ }^{13} \mathrm{C}\right]$ leucine. Isotopic enrichment of expired $\mathrm{CO}_{2}$ was measured by IRMS and dilution of ${ }^{13} \mathrm{C}$-KIC was measured by GCMS. Nitrogen excretion was measured in urine. The results (mean $\pm S D$, $\dagger$ sign.diff. at $p \leq 0.01$ ):

$\mathrm{N}$-balance Turnover Oxidation Synthesis Breakdown Balance $\mathrm{mg} / \mathrm{kg} / \mathrm{d} \quad \mu \mathrm{mol}$ leucine $/ \mathrm{kg} / \mathrm{hr}$

glucose $\quad-110 \pm 47 \quad 201 \pm 20 \quad 41 \pm 13 \quad 160 \pm 20 \quad 186 \pm 20 \quad-27 \pm 13$ glu + AA +45 $\pm 98+219 \pm 33 \quad 48 \pm 16 \quad 171 \pm 35 \quad 171 \pm 35+4 \pm 17 \dagger$ Conclusions: 1. Amino acid administration does not significantly alter leucine oxidation on the first day of life. 2. Even at a very low energy intake, amino acid administration of $1.2 \mathrm{~g} / \mathrm{kg} / \mathrm{d}$ prevents both negative leucine and nitrogen balances. Based upon protein balances, it seems that the administration of amino acids on the first day of life is benificial for preterm infants

MIXED MCT/LCT LIPID EMULSION USE IN SICK VLBW INFANTS David C Wilson, Henry L llalliday, Mark Reid, Garth McClure, John A Dodge. Department of Child Health, The Queen's University of Belfast and Royal Maternity Hospital, Belfast.

Undernutrition is common in sick VLBW infants requiring parenteral nutrition (PN). Lipid-free PN leads to poor energy intake but lipid has been associated with increased incidences of infection and BPD. Medium chain

triglycerides (MCT) are metabolised faster than long chain (LCT). We therefore designed a new PN regimen, with use of a 50 MCT emulsion from day 2 and in greater amounts. and compared this to a conventional pN regimen with 100 i and compared this to a conventional PN regimen with 1008
LCT emulsion. Sick VLBW infants were randomised to this LCT emulsion. Sick VLBW infants were randomised to this
new PN regimen (MCT) or control (LCT) groups; Lipof undin new PN regimen (MCT) or control (LCT) groups: Lipof und
MCT/LCT (B Braun) was used in the MCT group ( $=64$ ) and Intralipid (Kabi vitrum) in the LCT group $(n=61)$. The MCT Intralipid (Kabi Vitrum) in the LCT group $(n=61)$. The MC group had a mean BW of $925 \mathrm{~g}$ compared to $933 \mathrm{~g}$ in the
group. Mean energy intakes whilst receiving $\mathrm{PN}$ were greater $(p<0.001)$ in the MCT group at days $7,14,21,28,35$ and 42 . The incidences of BPD were 29 in the MCT group and 298 in the LCT group (ns), with infection rates of 638 and 748 respectively (ns). There were no significant increases in incidences of hyperlipidaemia or

hyperketonaemia in the MCT group. We conclude that

liberal MCT emulsion usage lessens undernutrition without adverse clinical or metabolic sequelae in sick preterms. 